\title{
MANAGEMENT LEARNING FOR CONSTRUCTION PROFESSIONALS. INQUIRES BENCHMARKS AND EXPERIENCES FROM POLAND, UNITED KINGDOM AND PORTUGAL
}

\author{
Kazimierz Cieszyński ${ }^{1}$, Andrzej Minasowicz ${ }^{2}$ and José Cardoso Teixeira ${ }^{3}$ \\ 1, 2 Warsaw University of Technology, Armii Ludowej 16, 00-637 Warsaw, Poland \\ ${ }^{3}$ Universtiy of Minho, Campus de Azeurem, 4700-058 Guimarćes, Portugal

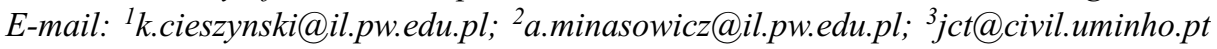

Received 21 February 2006; accepted 15 June 2006

\begin{abstract}
Management qualification of construction staff is an essential step towards Polish market development. Inquiries revealed the framework for qualification requirements that led to the establishment of a matrix of learning subjects. Learning requirements followed from that matrix and allowed for the definition of management learning profiles for construction professionals. These profiles have been compared to frameworks from other European institutions and lay the basis for defining training structures and learning programmes.
\end{abstract}

Keywords: Construction, Education, Management, Engineering.

\section{Introduction}

For half a century, the technical profile of Polish civil engineers was moulded by a centralised economical model that prevented management qualification of the construction staff. In the last twelve years Polish economy has evolved towards the free market model, but higher education of civil engineers has resisted catching up. This market shift has progressively affected the whole construction cluster leading to the establishment of thousands of private companies with variable aims. Making their way in the market encompasses many difficulties including lack of adequately prepared staff to fulfil management related functions. This is a common problem to all post communist countries now creating a free construction market from the basis.

The main purpose of the Polish education market in this specific area is the reconstruction of the scientific and lecturing potential and the generation of learning schemes. This can be achieved through the involvement of selected experts from a variety of academic and professional institutions throughout the country. Moreover, assistance from Western European countries is also essential so that the EU requirements for construction project management can be considered. Prior to defining staff and learning schemes however, the knowledge structure required had to established. Moreover, this would enable the search for specialists willing to participate in the project.
A set of two inquiries was conducted to Polish construction stakeholders aiming at clarifying:

- the qualification profiles required for construction engineering practice in Poland;

- the training programme to achieve those qualification profiles, including design methodology and lecturing staff;

- the characterisation of management demand for engineers.

The findings of the above inquiries evidence the gap between current educational profiles of civil engineering academic curricula and construction professional needs in the management field. Moreover, some suggestions were collected for new types of studies and learning subjects required [1]. The acknowledgement of this scenario led the basis for a research project with the following objective:

- to define the knowledge structure required for Polish construction professionals performing management duties and to establish the corresponding set of learning subjects.

In order to achieve this, the following two sub-objectives were settled:

- to benchmark graduate programmes offered by the EU higher education institutions in the field of construction project management; 
- to collect successful experiences from graduate programmes conducted in the EU countries.

Accordingly, a research team was organised with the following partners:

- Institute of Technology and Organization of Building Production. Civil Engineering Faculty. Warsaw University of Technology (WUT) - Poland.

- Polish British Construction Partnership (PBCP) Poland.

- Construction Management Education Foundation (FEMB) - Poland.

- European Construction Ventures (ECV) - UK.

- University of Minho (UM) - Portugal.

The Polish partners were responsible for the research and for co-ordinating information in order to achieve the first objective mentioned above. The United Kingdom is by far the EU country with most tradition in construction project management; therefore, ECV was selected to benchmark the UK higher education institutions offering training programmes on this field. Finally, the University of Minho has been running a successful MSc on Construction and Real Estate Management. This experience would be used to improve project results, thus they were committed to the third project objective.

The project was conducted from 1998 to 2001 in the scope of a Leonardo da Vinci Programme that also gained insights into the reality of other European Countries, especially in the British long tradition in the subject. The project was entitled Development of New Type of Studies and Courses in the Field of Management for Engineers According to the Requirements of European Union. This article briefly describes the work undertaken by each partner and discusses the main outputs of the project, according to objectives defined above.

\section{The Knowledge Structure for Managers in the Construction Environment}

The gap between current educational profiles and actual demands in the field of management in the construction activity is neither new nor exclusive of the Polish reality. Personnel managers of multinational industries have long realised their existence and no longer define the ideal recruit in terms of traditional knowledge and skills but are searching for young engineers with a 'plus' [2]. Angelides and Loukogeorgaki [3] found that after fundamental knowledge, information technology and project management are the two of the more required knowledge areas of a civil engineer and are present in most of the societal requirements of the profession. However, it has been claimed that civil engineering curricula devote less attention to the management topics than they should, taking into account the current professional demands on this field [4]; even the curricula that best fit professional demands are far from matching the actual job requirements. It is time therefore to increase the management focus in the civil engineering curriculum [5].

Most of the discussion on this topic has been concentrated on the professional competency required for managing construction projects which is obviously specific of the construction activity. In a survey to practitioners and to students enrolled in various Civil Engineering degree programmes at Lamar University, Koehn [6] concluded that several management subjects were recommended to have better learning coverage than they actually do. Although these subjects are not technical in nature, they may be extremely important for the overall management of engineering design and construction projects, this indicating that they should deserve additional attention from higher education institutions. Actually, knowledge and skills in the field of organization and management have been widely recognized as a board category of knowledge engineers will need in their future professional lives [2, 5].

Polish and Portuguese literature on this topic is scarce but a survey to international sources clearly confirms the results from the Polish inquiry. A survey to 170 project managers from the UK construction industry showed that formal training and job experience mostly contribute for delivering project management competency [7]. According to that survey, professional competency in project management is actually attained by the combination of knowledge acquired during training and skills developed through experience and the application of the acquired knowledge [7].

The outcomes of the ECV survey to the leading high education institutions in the UK evidenced that academic programmes in construction project management have been mostly tailored to the knowledge areas defined by the Accreditation Bodies relevant in this field [8]. Because Accreditation Bodies are professional associations, knowledge areas required have been defined according to the requirements of their members' practice. In some cases, frameworks of study have been set as well. The framework of the Chartered Institute of Building (CIOB) was found to be mostly followed by UK learning institutions and has been used for reference in a later section of this article [9]. Actually, CIOB is the leading UK professional body for managers in construction with over 40,000 members and severl branches around the world [10]. Despite these results refer to the British reality alone, it is quite reasonable to assume nowadays that they are applicable elsewhere in the world in view of the open construction market now established.

Several other sources may be investigated for establishing knowledge areas in this field. The reference material of the Project Management Institute (PMI) is probably the best known [11]. The Project Management Board of Knowledge (PMBoK) guide issued by the PMI is used for professional 
qualification and for the accreditation of educational programmes. It establishes nine general knowledge areas of management (integration, time, cost, procurement, quality, communications, risk, scope and human resources) each of which is further detailed on specific chapters of the guide. Knowledge areas of the PMBoK are basically the same for all possible working fields of project managers, ranging from research projects to construction projects. However, PMI released a Construction Extension to the PMBoK wich describes the PM knowledge and practice in the construction industry. This extension is currently being updated to the 2003 edition of the main standard [12]. Qualification and accreditation will certainly play an important role in the near future of engineering education but a unified European system does not exist for the moment [13].

Similarly to the UK, there is a growing movement towards certification of construction managers in the USA, in order to ensure that a construction manager has a certain body of knowledge, abilities, and experience. Both the American Institute of Constructors (AIC) [14] and the Construction Management Association of America (CMAA) [15] have established voluntary certification programmes for construction managers. According to the Occupation Outlook Handbook of the US Department of Labour, construction project managers need to understand contracts, plans, and specifications, and to be knowledgeable about construction methods, materials, and regulations. Familiarity with computers and software programs for job costing, online collaboration, scheduling, and estimating are also important [16].

Like in the UK, many colleges and universities of the USA offer degree programmes in construction management, foreseeing the application of their students to the above professional associations after some years of practice. Programmes are also similar to the ones found by ECV in their research in the UK [8]. Typical programmes include courses in project control and development, site planning, design, construction methods, construction materials, value analysis, cost estimating, scheduling, contract administration, accounting, business and financial management, safety, building codes and standards, inspection procedures, engineering and architectural sciences, mathematics, statistics, and information technology [16]. An example of this is the Construction Project Management Training offered by the San José State University of the USA that comprises a set of relevant modules, including Estimating, Safety Standards, Scheduling, Site Management, etc. [17].

Beyond Academia, it was useful to investigate course material from organisations specialised in individual and corporate training in the USA. ESI International, for example, offers a continuing education and development programme which has been designed for building project management skills, discipline, culture and focus, method- ologies and techniques [18]. Individual development is based on classroom or distant learning courses including specially designed courses for preparation of the Project Management Professional (PMP) Classification of the PMI; corporate training is structured into five areas, each containing a set of distinct courses, totaling more than one hundred. Another example is 4PM which is a project management firm offering PM mentoring over the web, on-site seminars and consulting [19]. Courses for individuals and for groups are availlable, as well as specially designed courses for the PMP of the PMI and for construction project management certification provided by a partner university. Two courses are required for the latter: Essentials of Construction Project Management and Managing Construction Projects, both of which dealing with cost estimation, project life cycle planning, motivation and other core skills of the profession. A third example of the survey undertaken is the Hampton Group, Inc that currently advertises a project management training package containing a core course on project initiation, planning, executing and controling and three adavnced modules on estimating, risk management and team building [20]. Course contents closely follow the knowledge areas defined at PMBoK.

Back in Europe, Thomas Telford Training from the Institute of Civil Engineers (ICE) of the UK provides a Construction Project Management course developed on the basis of the Code of Practice for Project Mangement [21]. The course is designed to cover all the relevant aspects of the profession in the project life cycle, from inception to completion, therefore following a different approach from the above examples. Similarly the Engineering Construction Industry Trainning Board (ECITB) presently provides a set of training courses in Construction managment topics throughout the UK. After consulting the Industry the ECITB decided for a suite of courses in the operational, tactical and strategic levels of project management and contracted Adept Knowledge Management Ltd to deliever the courses [22]. Beyond those, several specialist project managment courses are alos offered.

These are just but a few examples of sources that may be used for establishing knowledge areas in the field of construction project management. However, it has been claimed that knowledge areas required in practice transcend the scope covered by the Accreditation Bodies, because other general and management knowledge, coupled with skills that extend beyond the technical aspects of traditional engineering are also needed [7]. In view of the above discussion, this may also apply to educational institutions that are impeled to design their courses according to the requirements of Professional Associations, usually hosting the most relevant Accreditation Bodies. Combinig information from variuos sources as above, Edum-Fotwe and McCaffer suggest in their article [7] a set of knowledge and skill areas 
that they further decomposed into a number of several elements with direct impact on managers' performance.

\section{Work Undertaken}

Beyond investigating the knowledge structure for construction project managers as defined by international organisations, the accomplishment of the project objectives needed insights to the Polish construction industry, the benchmark of UK learning institutions and the report of the Portuguese experience.

Accordingly, Polish partners adopted a step by step approach, as described bellow:

- Identify organisational entities in the Polish construction cluster.

- Define leading management knowledge areas within organisational entities.

- Create the matrix of management learning subjects:

- each row relates to each organisational unit;

- each column refers to each discipline of knowledge required;

- each cell focuses on specific learning subject required to perform management duties on each particular management discipline within each specific organisational unit.

Several documents have been produced on the results of this survey $[1,23]$. The British partner surveyed a set of UK leading higher education institutions and collected information on the knowledge structure and the learning subjects adopted by those institutions in their programmes [8]. The Portuguese partner provided information on MSc's conducted in Portugal, with special emphasis on the Msc on Construction and Real Estate Management programme of University of Minho [24].

The results of this work allowed for the definition of the knowledge structure and for the settlement of the corresponding learning subjects, as required by the aims of the project.

\section{Matrix of Management Learning Subjects}

A set of five basic organisation units has been identified and a set of five disciplines of knowledge has been defined, leading to 14 different learning subjects. The following sections present a discussion on matrix rows, columns and cells.

\subsection{Organisational Entities}

Organisations presently operating in the Polish construction cluster have the following basic characteristics:

- aim at achieving specific aims, fulfilling specific functions;

- may be described by their structure, which determines qualification to fulfil functions;

- follow a specific form of company act;

- have a market value;

- develop their operations in agreement with market opportunities and restrictions;

- have a specific management system.

The following types of organisation entities could be identified:

- Industrial production units. This is a characteristic production process of a number of organisational entities with great relevance in the construction clus-
Distribution of Polish construction firms by activity

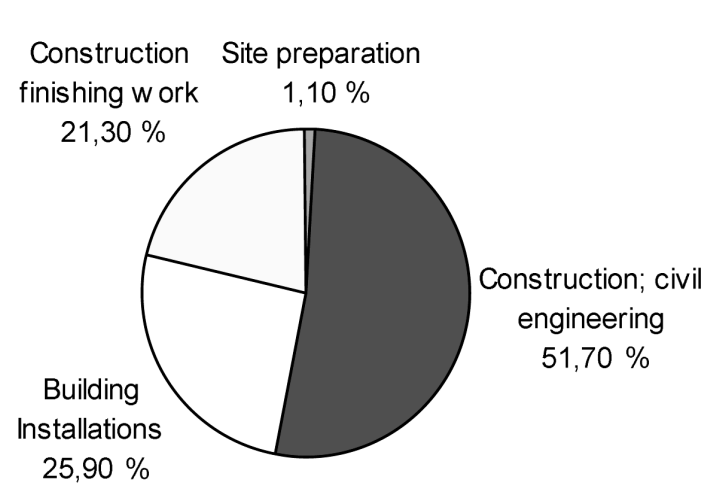

Distribution of Polish construction firms by the number of employees

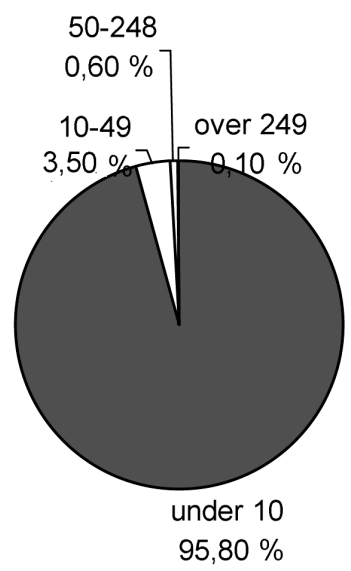

Source: REGON Register; GUS 2002

Fig 1. Construction market structure in Poland at 30 June 2002 


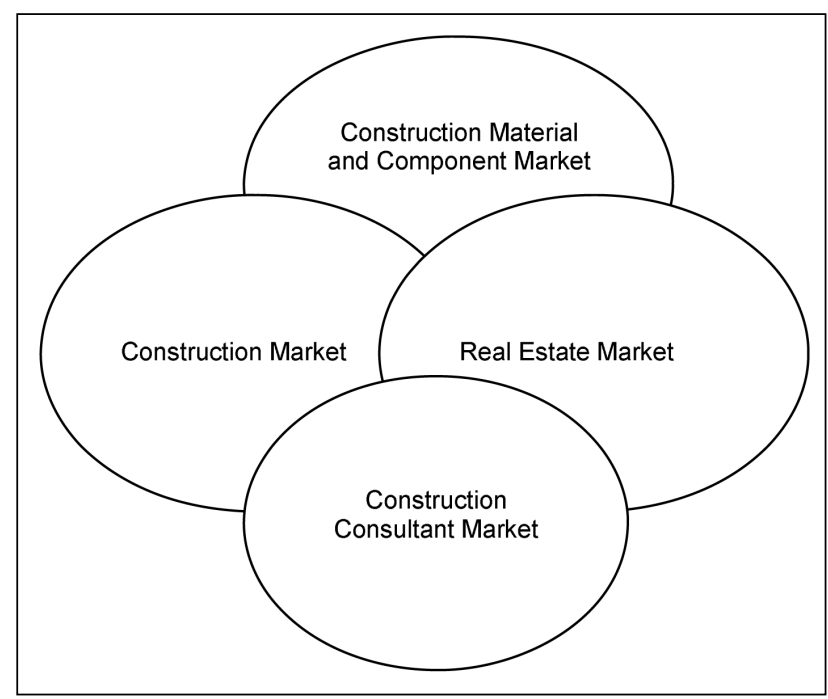

Fig 2. Interaction among markets in the construction cluster

ter (for example, raw materials, construction and building materials, pre-cast elements, building components, etc.). This type of entities normally acts as suppliers to construction companies, but should not be included in the construction market. Although companies concerned pertain to different industrial sectors, they may be considered to operate in the construction material and component market.

- Construction companies. Presently, there is a variety of construction companies operating in the Polish construction market. Figure 1 depicts the construction market structure in Poland. For the aims of this study, labour suppliers and equipment suppliers are included in this entity set.

- Consultants. This entity set is a growing component of the construction cluster. Consultants have gained importance, variety and complexity over the last few years in Poland, and it is expected that they will keep on improving in the future. Some examples are, designers; project mangers; technical specialists; quality, safety and environmental managers; quantity surveyors; etc.). Despite the differences among them, for the aims of this study, they may be considered to act in the construction consultant market.

- Construction clients. This entity set includes private and public organisations acting as construction clients. They act both in the construction market and in the real estate market.

Fig 2 bellow shows how different markets mentioned above interact.

\subsection{Management Knowledge Areas}

The next step aimed at identifying leading management knowledge areas required to engineers is concerned in each organisational entity defined above. These areas can also be viewed as professional functions of engineers involved in management duties in the construction activity. Conclusions of this study are summarised below:

- Obviously, company management is a common topic to all organisational entities and, according to the inquiries, Polish civil engineers may be involved in management duties an a company level in all of them.

- Industrial production units often employ civil engineers to perform management functions on the production level. Their duties are mostly related to production management that was identified as the representative management area.

- Construction management is the broad management knowledge area required to engineers working in the production area of construction companies.

- Consultant organisations lead with a variety of project related issues; it may be stated that the knowledge area required to perform their duties is project management.

- Client organisations are mostly concerned with facility management.

Boundaries among the above management knowledge areas are blurred because of the variety of duties that engineers may possibly perform in each organisation entity. Accordingly, a construction manager working in a construction company may be involved in a project management activity; client organisations may require project management knowledge for their engineers, etc.

\subsection{Disciplines of Knowledge}

According to inquiries to Polish construction managers [1], the following five relevant disciplines of knowledge or scientific areas have been identified [23]:

- Object - This discipline aims to include the learning subjects mostly concerned to the production object of each organisation entity identified.

- Subject - This discipline ought to include management learning on the subjects of production, that is people and materials.

- Technology - This discipline deals with technical means and components required to perform the production outputs of each type of organisational entity identified.

- Organisation and Regulation - Under this tittle, a variety of learning subjects should be included, like organisational and functional systems, quality assurance, production systems, commercial law and regulations, and so on. Specific learning subjects will be selected for each organisational entity identified.

- Economics and Finances - The scope of this discipline covers subjects on management economics, cost estimation, valuations and financial analysis tailored to each organisational entity identified. 
Table 1. Matrix of Management Learning Subjects

\begin{tabular}{|c|c|c|c|c|c|c|c|}
\hline & \multirow{3}{*}{$\begin{array}{l}\text { Organisation } \\
\text { entities }\end{array}$} & \multirow{3}{*}{$\begin{array}{c}\text { Leading } \\
\text { management } \\
\text { knowledge areas }\end{array}$} & 1 & 2 & \begin{tabular}{|c|}
3 \\
\end{tabular} & 4 & 5 \\
\hline & & & & & \multicolumn{3}{|c|}{ Disciplines of knowledge } \\
\hline & & & Object & Subject & Technology & $\begin{array}{c}\text { Organisation } \\
\text { and Regulation }\end{array}$ & $\begin{array}{l}\text { Economics and } \\
\text { Finances }\end{array}$ \\
\hline $\mathbf{A}$ & All & $\begin{array}{l}\text { Company } \\
\text { management }\end{array}$ & Various & $\begin{array}{c}\text { Human resource } \\
\text { management }\end{array}$ & & $\begin{array}{c}\text { Company } \\
\text { administration } \\
\text { and organisation }\end{array}$ & $\begin{array}{c}\text { Management } \\
\text { economics }\end{array}$ \\
\hline B & Industries & $\begin{array}{l}\text { Production } \\
\text { management }\end{array}$ & $\begin{array}{c}\text { Building } \\
\text { materials and } \\
\text { components }\end{array}$ & \multirow[t]{2}{*}{$\begin{array}{l}\text { Health and safety } \\
\text { management }\end{array}$} & $\begin{array}{l}\text { Production } \\
\text { Technology }\end{array}$ & $\begin{array}{l}\text { Production } \\
\text { planning and } \\
\text { control }\end{array}$ & \multirow[t]{2}{*}{$\begin{array}{l}\text { Estimating and } \\
\text { tendering }\end{array}$} \\
\hline $\bar{C}$ & $\begin{array}{l}\text { Construction } \\
\text { Companies }\end{array}$ & $\begin{array}{l}\text { Construction } \\
\text { management }\end{array}$ & \multirow[t]{2}{*}{ Construction projects } & & $\begin{array}{l}\text { Construction } \\
\text { Technology }\end{array}$ & Site management & \\
\hline D & Consultants & $\begin{array}{c}\text { Project } \\
\text { management }\end{array}$ & & $\begin{array}{l}\text { Quality and } \\
\text { environmental } \\
\text { management }\end{array}$ & \multicolumn{2}{|c|}{$\begin{array}{c}\text { Project life cycle planning, monitoring and } \\
\text { control }\end{array}$} & $\begin{array}{l}\text { Investment analysis } \\
\text { and valuations }\end{array}$ \\
\hline $\mathbf{E}$ & Clients & $\begin{array}{c}\text { Facility } \\
\text { management }\end{array}$ & $\begin{array}{l}\text { Construction } \\
\text { facilities }\end{array}$ & & $\begin{array}{l}\text { Conservation, } \\
\text { maintenance and } \\
\text { life use }\end{array}$ & $\begin{array}{c}\text { Building asset } \\
\text { management }\end{array}$ & \\
\hline
\end{tabular}

Table 1 presents the final version of the Matrix of Management Learning Subjects achieved by the project. Management formative subjects are located in columns 2, 4 and 5, informative subjects in column 1 and technological subjects in column 3. Some subjects are common to more than a row, indicating that they may be required to several organisational entities, and other subjects are common to more than one column suggesting that they belong to several disciplines of knowledge.

\section{Portuguese Survey}

\subsection{Undergraduate Level}

Presently, there are sixteen higher education institutions in Portugal, offering a five year undergraduate degree in civil engineering. This corresponds to the 'long cycle' model for engineering education with roots in the German and French schools of the 19th century [25] holding a strong theoretical basis and covering a quite broad programme in a variety of areas such as structures, foundations, hydraulics, construction materials, construction technology, roads, town planning, etc. Things may actually change in a near future in view of the objective envisaged by the Bologna
Declaration of a 'two tier' system for engineering education across Europe by 2010 [25]. For the moment however, there is an increasing tendency for adopting a four year base course and a final year for specialisation rather than matching the above objective. But no specific specialisation in construction management or project management could be found in the course of the survey. Management related courses have mostly been included into the construction technology area, either during the first four years or on the final year of specialisation in this area. Typical management related courses include the following learning subjects:

- Economic science (economic data; micro economics for construction and macroeconomic variables; fundamentals of finance mathematics and economic engineering).

- Corporate Management (organisation theory, strategic management, management accounting, cost analysis, human resources, stock management).

- Project Management (project management team, project planning, quality planning and certification).

- Estimating and tendering.

- Construction site management (site installation, site management, site plant and equipment, site safety). 
- Construction planning (construction project planning and control).

This set of learning subjects approximately fits into cells A4-A5, C2, C4-C5 and D3-D4 of Table 1, but no extensive cover of these subjects may be achieved at this level of studies. Moreover, some courses are optional in some institutions, and may not be selected by students seeking for a broader specialisation in Construction Technology. On the other hand, subjects included in cells B1, C1-D1 and C3 seem to be adequately covered by the above programmes. Learning subjects of row E (Facility Management) could not be clearly found at the undergraduate level. Cells of Table 2 are shaded according to the results of this survey.

\subsection{Graduate Level}

Civil Engineering Departments of the following Portuguese learning institutions offer the most recognised MSc courses:

- Universidade do Minho (UM) [26]

- Faculdade de Engenharia da Universidade do Porto (FEUP) [27]
- Faculdade de Ciźncias Técnicas da Universidade de Coimbra (FCTUC) [28].

- Instituto Superior Técnico da Universidade Técnica de Lisboa (IST-UTL) [29].

All of them offer a set of distinct MSc courses in different civil engineering specialisation areas (commonly, the same specialisation areas of undergraduate programmes) possibly further divided, according to each area (e.g. concrete structures, steel structures, computational mechanics, etc.). Four main approaches for construction management topics in MSc programmes are currently considered in the above institutions:

- Construction management topics are organised into an introduction course, pertaining to a basic module (as in MSc in Municipal Engineering of UM).

- Construction management topics are included into MSc programmes in Construction (as in the MSc in Civil Engineering - Construction Technology and Management branch of UM, in the MSc in Construction Sciences of FCTUC and in the MSc in Building Construction of FEUP).

- Construction Management is a specific scientific

Table 2. Learning subjects covered by Portuguese civil engineering undergraduate level programmes

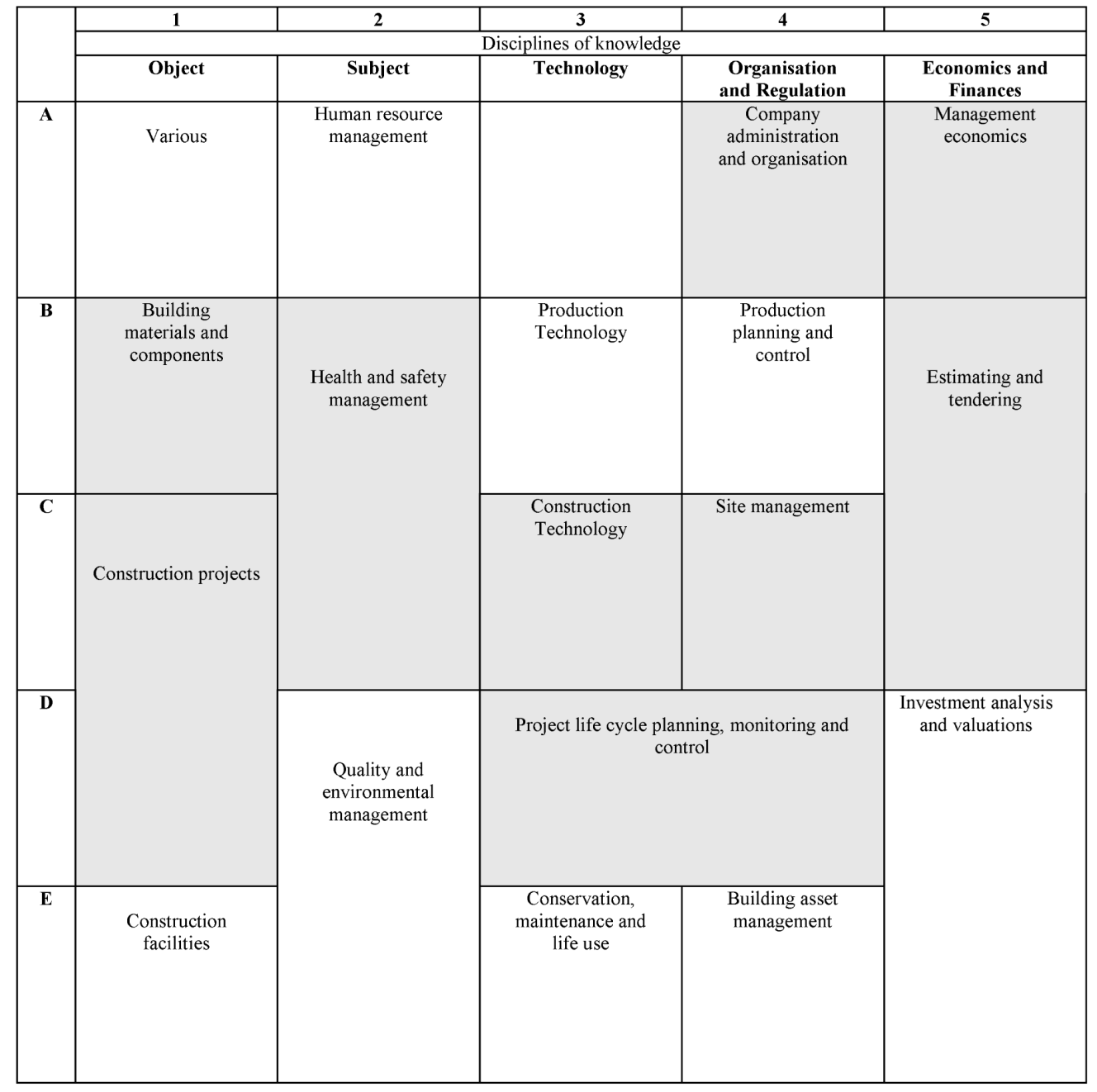


area of a MSc programme in Construction (as in the MSc in Construction of IST), thus providing a full specialisation.

- Construction Management is an independent MSc degree (as in the MSc in Construction Management and Real Estate of UM).

For the aims of this survey, only the last two approaches seem relevant and are further discussed hereinafter.

The set of learning subjects of MSc in Construction (Construction Management and Economics Branch) offered by IST seems to adequately cover all management formative subjects of table 1 (columns 2, 4 and 5) for construction management and project management domains (rows $\mathrm{C}$ and $\mathrm{D}$ ) and to a lesser extent for company management (row A). Production management and facility management do not seem to be adequately addressed by this programme. There are, however, some additional subjects in this MSc which could not be directly linked to the table cells.

The set of learning subjects of the MSc in Construction Management and Real Estate offered by UM seems to fit a great part of learning subjects found in table 1 [24]. However, some subjects seem not to fit, because they are ad- dressed at the undergraduate level (namely, those of columns 1 and 3) and others are clearly out of scope (in row B). There are also some more subjects in this MSc which could not be fitted to the table cells. Cells of Table 3 are shaded according to the results of this survey.

\section{Matrix of Learning Requirements}

The Matrix of Management Learning Subjects, as presented in Table 1 above, shows that some learning subjects should be included in the learning profiles of engineers aiming to have distinct professional functions. This principle has been further developed, leading to the Matrix of Management Learning Requirements for construction professionals as shown in Table 4. Only management formative subjects have been considered, that is, 11 different subjects pertaining to columns 2, 4 and to 5 of Table 1 . Accordingly,

- each row relates to a specific learning subject;

- each column refers to a management professional function;

- bullets in cells indicate the importance of the learn-

Table 3. Learning subjects covered by the MSc in Construction Management and Real Estate of University of Minho, Portugal

\begin{tabular}{|c|c|c|c|c|c|}
\hline & 1 & 2 & 3 & 4 & 5 \\
\hline & \multicolumn{5}{|c|}{ Disciplines of knowledge } \\
\hline & Object & Subject & Technology & $\begin{array}{c}\text { Organisation } \\
\text { and Regulation }\end{array}$ & $\begin{array}{l}\text { Economics and } \\
\text { Finances }\end{array}$ \\
\hline $\mathbf{A}$ & Various & $\begin{array}{l}\text { Human resource } \\
\text { management }\end{array}$ & & $\begin{array}{c}\text { Company } \\
\text { administration } \\
\text { and organisation }\end{array}$ & $\begin{array}{l}\text { Management } \\
\text { economics }\end{array}$ \\
\hline B & $\begin{array}{l}\text { Building } \\
\text { materials and } \\
\text { components }\end{array}$ & \multirow[t]{2}{*}{$\begin{array}{l}\text { Health and safety } \\
\text { management }\end{array}$} & $\begin{array}{l}\text { Production } \\
\text { Technology }\end{array}$ & $\begin{array}{l}\text { Production } \\
\text { planning and } \\
\text { control }\end{array}$ & \multirow[t]{2}{*}{$\begin{array}{l}\text { Estimating and } \\
\text { tendering }\end{array}$} \\
\hline $\bar{C}$ & \multirow[t]{2}{*}{ Construction projects } & & $\begin{array}{l}\text { Construction } \\
\text { Technology }\end{array}$ & Site management & \\
\hline D & & $\begin{array}{l}\text { Quality and } \\
\text { environmental } \\
\text { management }\end{array}$ & \multicolumn{2}{|c|}{$\begin{array}{l}\text { Project life cycle planning, monitoring and } \\
\text { control }\end{array}$} & $\begin{array}{l}\text { Investment analysis } \\
\text { and valuations }\end{array}$ \\
\hline $\mathbf{E}$ & $\begin{array}{l}\text { Construction } \\
\text { facilities }\end{array}$ & & $\begin{array}{l}\text { Conservation, } \\
\text { maintenance and } \\
\text { life use }\end{array}$ & $\begin{array}{c}\text { Building asset } \\
\text { management }\end{array}$ & \\
\hline
\end{tabular}


Table 4. Matrix of Management Learning Requirements

\begin{tabular}{|c|c|c|c|c|c|}
\hline \multicolumn{6}{|c|}{ Investment analysis and valuations } \\
\hline \multicolumn{6}{|c|}{ Estimating and tendering } \\
\hline \multicolumn{6}{|c|}{ Management Economics } \\
\hline \multicolumn{6}{|c|}{ Building asset management } \\
\hline \multicolumn{6}{|c|}{$\begin{array}{l}\text { Project life cycle planning, } \\
\text { monitoring and control }\end{array}$} \\
\hline \multicolumn{6}{|c|}{ Site management } \\
\hline \multicolumn{6}{|c|}{ Production planning and control } \\
\hline \multicolumn{6}{|c|}{$\begin{array}{l}\text { Company administration and } \\
\text { organisation }\end{array}$} \\
\hline \multicolumn{6}{|c|}{$\begin{array}{l}\text { Quality and environmental } \\
\text { management }\end{array}$} \\
\hline \multicolumn{6}{|c|}{ Health and Safety management } \\
\hline \multicolumn{6}{|c|}{ Human resource management } \\
\hline 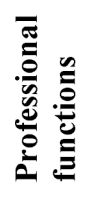 & 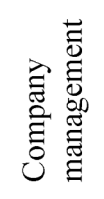 & 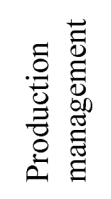 & 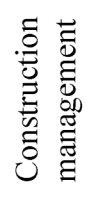 & 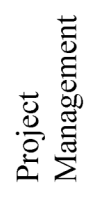 & 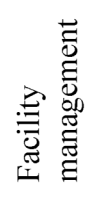 \\
\hline
\end{tabular}

ing subject for the corresponding professional function.

Bullets are graded differently, according to the importance of the learning subject for each professional profile. Darker ones indicate the most important learning subjects.

The results summarised in Table 4 allowed for the establishment of the management learning profiles listed in table 5 below [30]. For each professional function, two sets of learning subjects are presented. The first set corresponds to the most important ones which have been identified with darker bullets in the cells of Table 4; the second set corresponds to less important learning subjects, which have been marked with bullets closer to white. Most important subjects are placed in darker cells of Table 5 .

\section{The CIOB Education Framework}

Conclusions of the preceding studies have been compared to level 3 - Professional Studies of the Educational Framework of CIOB [9]. Table 6 below summarises the current module structure adopted by CIOB.

\section{Conclusions}

Departing from the results of inquiries to Polish construction stakeholders and using European experience on training management for construction professionals, a matrix of learning subjects could be established fitting Polish current reality. Management learning requirements have then been inferred, according to management knowledge required to construction professionals. Hence, management learning profiles for construction professionals could be established for five distinct professional functions (Table 5). These results have been compared to CIOB framework for professional studies, leading to the following conclusions:

- Similarities between both tables are most obvious for facility management, construction management and project management professional functions.

- Company management and Production management professional functions have been identified from the inquiries in Poland but are not considered in CIOB framework, evidencing distinct concerns and possibly distinct participation of engineers in this function in Poland and in the UK. 
Table 5. Management Learning Profiles for construction professionals

\begin{tabular}{|c|c|}
\hline $\begin{array}{c}\text { Profes- } \\
\text { sional } \\
\text { Functions }\end{array}$ & Learning Profiles \\
\hline \multirow[t]{2}{*}{$\begin{array}{l}\text { Company } \\
\text { mana- } \\
\text { gement }\end{array}$} & $\begin{array}{l}\text { Human resource management } \\
\text { Company administration and organisation } \\
\text { Management economics }\end{array}$ \\
\hline & Quality and environmental management \\
\hline \multirow{2}{*}{$\begin{array}{l}\text { Pro- } \\
\text { duction } \\
\text { mana- } \\
\text { gement }\end{array}$} & $\begin{array}{l}\text { Health and safety management } \\
\text { Production planning and control } \\
\text { Estimating and tendering }\end{array}$ \\
\hline & $\begin{array}{l}\text { Human resource management } \\
\text { Quality and environmental management } \\
\text { Company administration and organisation }\end{array}$ \\
\hline \multirow[t]{2}{*}{$\begin{array}{l}\text { Const- } \\
\text { ruction } \\
\text { mana- } \\
\text { gement }\end{array}$} & $\begin{array}{l}\text { Health and safety management } \\
\text { Quality and environmental management } \\
\text { Site management } \\
\text { Project life cycle planning, monitoring and control } \\
\text { Estimating and tendering }\end{array}$ \\
\hline & $\begin{array}{l}\text { Human resource management } \\
\text { Company administration and organisation } \\
\text { Management economics }\end{array}$ \\
\hline \multirow{2}{*}{$\begin{array}{l}\text { Project } \\
\text { mana- } \\
\text { gement }\end{array}$} & $\begin{array}{l}\text { Health and safety management } \\
\text { Quality and environmental management } \\
\text { Site managemen } \\
\text { Project life cycle planning, monitoring and control } \\
\text { Investment analysis and valuations }\end{array}$ \\
\hline & $\begin{array}{l}\text { Human resource management } \\
\text { Company administration and organisation } \\
\text { Building asset management } \\
\text { Management economics } \\
\text { Estimating and tendering }\end{array}$ \\
\hline \multirow[b]{2}{*}{$\begin{array}{l}\text { Facility } \\
\text { mana- } \\
\text { gement }\end{array}$} & $\begin{array}{l}\text { Quality and environmental management } \\
\text { Building asset management } \\
\text { Investment analysis and valuations }\end{array}$ \\
\hline & $\begin{array}{l}\text { Human resource management } \\
\text { Health and safety management } \\
\text { Company administration and organisation } \\
\text { Project life cycle planning, monitoring and control } \\
\text { Management economics } \\
\text { Estimating and tendering }\end{array}$ \\
\hline
\end{tabular}

The above results are useful for defining training structures and learning programmes, this being the object of a further Leonardo project under way.

\section{References}

1. Development of New Management Studies and Courses in the Field of Management in Construction for Engineers According to the Requirements of European Union. Product 1: Re-
Table 6. CIOB Framework for Professional Studies

\begin{tabular}{|c|c|}
\hline $\begin{array}{c}\text { Profes- } \\
\text { sional } \\
\text { Functions } \\
\end{array}$ & Modules \\
\hline $\begin{array}{l}\text { Facilities } \\
\text { mana- } \\
\text { gement }\end{array}$ & $\begin{array}{l}\text { The practice environment } \\
\text { Strategic property management } \\
\text { Valuations } \\
\text { Built asset management } \\
\text { Organisation, people and processes } \\
\text { Contract procedures }\end{array}$ \\
\hline $\begin{array}{l}\text { Commer- } \\
\text { cial } \\
\text { mana- } \\
\text { gement }\end{array}$ & $\begin{array}{l}\text { Design, costing and contro } \\
\text { Estimating and tendering } \\
\text { Cost management systems } \\
\text { Contractual procedures }\end{array}$ \\
\hline $\begin{array}{l}\text { Project } \\
\text { mana- } \\
\text { gement }\end{array}$ & $\begin{array}{l}\text { The development process } \\
\text { Fundamentals of project management } \\
\text { Project planning, monitoring and control }\end{array}$ \\
\hline $\begin{array}{l}\text { Construc- } \\
\text { tion } \\
\text { mana- } \\
\text { gement }\end{array}$ & $\begin{array}{l}\text { Building management } \\
\text { Contractual procedures } \\
\text { Planning, programming and production } \\
\text { Site management }\end{array}$ \\
\hline $\begin{array}{l}\text { Produc- } \\
\text { tion } \\
\text { design } \\
\text { mana- } \\
\text { gement }\end{array}$ & $\begin{array}{l}\text { Architectural technology } \\
\text { Building services engineering } \\
\text { Management of production design } \\
\text { Organisation, people and processes } \\
\text { Conservation and life use } \\
\text { Structural design }\end{array}$ \\
\hline
\end{tabular}

sults of the Questionnaire among Construction Engineers and Managers Regarding Actual Educational Needs and Raising of Managerial Skills, 2002.

2. De Graaff, Erik; Ravesteinjn, Wim. Training complete engineers: global enterprise and engineering education. European Journal of Engineering Education, Vol 26, No 4, 2001, p. 419427.

3. Angelides, Demos C. and Loukogeorgaki, Eva. A strategic approach for supporting the future of civil engineering education in Europe. European Journal of Engineering Education, Vol 30, No 1, 2003, p. 37-50.

4. Christodoulou, Symeon. Educating Civil Engineering Professionals of Tomorrow. Journal of Professional Issues in Engineering Education and Practice, April 2004.

5. Chinowsky, Paul S. Integrating Management Breadth in Civil Engineering Education. Journal of Professional Issues in Engineering Education and Practice, July 2002.

6. Koehn, Enno. ABET Program Criteria: Review and Assessment for Civil Engineering Program. Journal of Engineering Education, Vol 90, No 3, 2001, p. 445-455.

7. Edum-Fotwe, F. T.; McCaffer, R. Developing project management competency: perspectives from the construction industry. International Journal of Project Management, 18, 2000, p. 111-124.

8. Development of New Management Studies and Courses in the Field of Management in Construction for Engineers 
According to the Requirements of European Union. Product 7: UK survey, 2002.

9. Knowledge Framework $C I O B$.

10. http://www.ciob.org.uk/ (site visited on the 1st December 2005)

11. D Duncan, W. R. A guide to the project management body of knowledge. Project Management Institute Standards Committee, Upper Darby PA: PMI, 1996.

12. http://www.pmi.org/ (site visited on the 1st December 2005)

13. Manoliu, I. Civil engineering in the context of the European Higher Education Area - the role of EUCEET, inquiries into the European higher education in civil engineering. EUCEET Socrates-Erasmus Thematic Network Project. In: I. Manoliu and T. Bugnariu (eds). European Civil Engineering Education and Training, 2001a, 1st EUCEET Vol, 2001, p. 43-87.

14. http://www.aicnet.org/ (site visited on the 1st December 2005)

15. http://cmaanet.org/ (site visited on the 1st December 2005)

16. http://stats.bls.gov/ (site visited on the 1st December 2005)

17. http://cts.sjsu.edu/ (site visited on the 1st December 2005)

18. http://www.esi-europe.com/ (site visited on the 1st December 2005)

19. http://www.4pm.com/ (site visited on the 1st December 2005)

20. http://www.projectmanagertrainig.com/ (site visited on the 1st December 2005)

21. http://www.ttrain.co.uk/ (site visited on the 1st December 2005)
22. http://www.ecitb.org.uk/ (site visited on the 1st December 2005)

23. Development of New Management Studies and Courses in the Field of Management in Construction for Engineers According to the Requirements of European Union. Product 2: Structure of Knowledge for the Faculty of Construction Engineering and Management, 2002.

24. Development of New Management Studies and Courses in the Field of Management in Construction for Engineers According to the Requirements of European Union. Product 3: Report on Portuguese survey, 2002.

25. Maffioli, Francesco; Augusti, Giuliano. Tuning engineering education into the European Higher Education Orchestra. European Journal of Engineering Education, Vol 28, No 3, 2003, p. 251-273.

26. http://www.uminho.pt/ (site visited on the 30 th June 2002)

27. http://www.fe.up.pt/ (site visited on the 30 th June 2002)

28. http://www.fct.uc.pt/ (site visited on the 30 th June 2002)

29. http://www.ist.utl.pt/ (site visited on the 30 th June 2002)

30. Development of New Management Studies and Courses in the Field of Management in Construction for Engineers According to the Requirements of European Union. Product 6: Draft Proposal for Future Certification of Managerial Qualification System for Construction Engineers and Accreditation of Systems for Relevant Courses, 2002.

\section{STATYBOS SPECIALISTŲ VADYBOS ŽINIŲ GILINIMAS: LENKIJOS, JUNGTINĖS KARALYSTE்S IR PORTUGALIJOS PATIRTIS IR LYGINAMOJI ANALIZE்}

\section{K. Cieszyński, A. Minasowicz ir J. C. Teixeira}

\section{Santrauka}

Statybos personalo parengimo gerinimas vadybos srityje yra būtinas žingsnis Lenkijos konkurencingumui didinti. Atlikta apklausa atskleidè kvalifikacinių reikalavimų struktūrą, pagal kurią sudaryta reikalingų studijuoti dalykų matrica. Iš šios matricos suformuluoti reikalavimai žinioms, pagal juos sudaryti vadybos studijų dalykai statybos specialistams. Kuriant studijų struktūros ir mokymo programų bazę, sudarytasis dalykų sąrašas buvo palygintas su analogiškais kitų Europos institucijų sąrašais.

Reikšminiai žodžiai: statyba, ugdymas, vadyba, inžinerija.

Kazimierz CIESZYŃSKI. Professor, Department of Construction Engineering and Management, Civil Engineering Faculty, Warsaw University of Technology.

First degree in civil engineering, Warsaw University of Technology (1952), Master of Science (1954), PhD. Eng. (1964), DSc. (1969), Professor (1979). Practices in connection with "TEMPUS" Project in German speaking countries (1991-1992), essential coordination in Leonardo da Vinci Project "Development of new type of studies and courses in the field of management in construction for engineers according to the requirements of European Union" (1999-2001), scientific consultant in Leonardo da Vinci Project "Model of professional qualification structure and new methods of promotion, certification and mutual recognition of managerial skills in construction industry according to EU requirements" (2002-2004), initiation of educational specialty "Management and engineering production in construction" at Higher School of International Commerce and Finance (since 2003).

Former Director of Construction Engineering and Management Department at Civil Engineering Faculty of Warsaw University of Technology, member of CIOB from 2005, round 200 scientific publications - in those 15 books, promoter of 11 doctors in technical science.

Research interests: construction technology and organisation, project management, management in construction. 
Andrzej MINASOWICZ. PhD Eng., Lecturer in Department of Construction Engineering and Management, Civil Engineering Faculty, Warsaw University of Technology.

First degree in civil engineering, Warsaw University of Technology, Master of Science (1968), PhD (1976). Work on the project „Expert system for site's installation“ at University of Karlsruhe (1991), co-ordinator of the Leonardo da Vinci Project "Development of new type of studies and courses in the field of management in construction for engineers according to the requirements of european union" (1999-2001), co-ordinator of the Leonardo da Vinci Project "Improvement of the linguistic skills of polish and portuguese construction managers and engineers - recognition of needs and preparation of courses in construction english language" (2001-2004), co-ordinator of the Leonardo da Vinci Project: "Model of professional qualifications structure and new methods of promotion, certification and mutual recognition of managerial skills in construction industry according to the requirements of EU" (2002-2004).

Vice Director of Construction Engineering and Management Department at Civil Engineering Faculty of Warsaw University of Technology, President of Polish British Construction Partnership Sp. z o.o., Fellow of The Chartered Institute of Building (FCIOB) from 2005, Member of Association of Consulting Engineers and Experts (SIDIR), Fellow of Institution of Civil Engineering (ICE), Member of The Association for Total Cost Management, Member of American Association of Cost Estimators (AACE), Member of Science Association of Construction Process Engineering, President of Polish Association of Building Managers (2005)

Research interests: management in construction, risk management.

José Cardoso TEIXEIRA. Graduation in Civil Engineering by Faculdade de Engenharia do Porto, in 1981, with final classification of 16. MSc in Building Construction by Faculdade de Engenharia da Universidade do Porto in October 1988 with final classification of MB. PhD in Construction Management by Loughborough University of Technology (United Kingdom) in October 1994.

Lecturing at Universidade do Minho since May 1982 in Civil Engineering Course. Assistant Trainee from 1 July 1985 to 3 November 1988. Assistant from 4 November 1988 to 3 December 1994. Auxiliary Professor from 4 December 1994 to 12 July 2000. Associate Professor from 13 July 2001. He has been responsible for several courses in the field of Management and Technology of Construction of the five year undergraduate programme at the University of Minho. He has also been responsible for several courses of MSc programmes in Municipal Engineering, Civil Engineering, Construction and Real Estate Management and Human Engineering at the

University of Minho. He has also lectured several professional courses at various institutions. He has been supervisor of final projects of undergraduates and several MSc and $\mathrm{PhD}$ dissertations.

Research interests: construction technology, construction project management, safety and environment in construction, sustainability. 